\title{
Surgical treatment of projectile in the infratemporal fossa. Case report
}

\author{
Tratamento cirúrgico de um projétil na fossa infratemporal. Relato de caso
}

Eduardo Grossmann ${ }^{1}$, Luciano Ambrosio Ferreira²

DOI 10.5935/1806-0013.20160077

\section{ABSTRACT}

BACKGROUND AND OBJECTIVES: Gunshot wounds may have fatal results. Even when not causing major injuries to soft and hard tissues, there may be other severe problems. This study aimed at reporting the case of a projectile located in the left infratemporal fossa and at discussing treatment, risks and complications.

CASE REPORT: Male patient, 18 years old, suffered a gunshot wound which has penetrated the face by the left zygomatic region, and was lodged in the homolateral infratemporal fossa. This has caused jaw function impairment and pain. Foreign body was surgically removed by preauricular access and patient was then submitted to physiotherapy. After treatment, temporomandibular joint function was reestablished and esthetic results were considered excellent without sequelae.

CONCLUSION: Management of patients hit by projectiles is more complex when these are located in an area of difficult access and close to noble structures. Radiographic techniques obtained by means of different planes allow the accurate location of the object. There may be major deformity and functional incapacity, especially if the facial nerve is affected during bullet trauma or during surgery. Although there were no nervous injuries, functional impairment of orofacial structures was decisive to indicate the surgical procedure. Surgical removal of the projectile from the infratemporal fossa, combined with postoperative physiotherapy, has shown to be an effective treatment.

Keywords: Infratemporal fossa, Projectile, Rehabilitation, Temporomandibular joint.
1. Universidade Federal do Rio Grande do Sul, Porto Alegre, RS, Brasil.

2. Faculdade de Ciências Médicas e da Saúde, - Suprema, Hospital Maternidade Therezinha de Jesus, Juiz de Fora, MG, Brasil.

Submitted in April 12, 2016.

Accepted for publication in June 20, 2016.

Conflict of interests: none - Sponsoring sources: none.

Correspondence to:

Coronel Corte Real, 513 - Petrópolis

90630-080 Porto Alegre, RS, Brasil.

E-mail: edugdor@gmail.com

(C) Sociedade Brasileira para o Estudo da Dor

\section{RESUMO}

JUSTIFICATIVA E OBJETIVOS: Ferimentos causados por arma de fogo podem ter resultados fatais. Mesmo que a bala não cause grandes lesóes para os tecidos moles e duros, outros problemas graves podem ocorrer. O objetivo deste estudo foi relatar o caso de um projétil localizado na fossa infratemporal esquerda, discutir o tratamento cirúrgico, seus riscos e complicaçóes.

RELATO DO CASO: Paciente do gênero masculino, 18 anos, sofreu um ferimento por arma de fogo que penetrou na face pela regiāo zigomática esquerda, alojando-se na fossa infratemporal homolateral. Esse ocasionou comprometimento da funçáo mandibular e dor. O corpo estranho foi removido cirurgicamente por meio do acesso pré-auricular e o paciente foi posteriormente submetido a sessóes de fisioterapia. Após o tratamento, foi reestabelecida a função da articulação temporomandibular, a dor desapareceu e os resultados estéticos foram considerados excelentes, sem sequelas.

CONCLUSÁO: O manuseio dos pacientes acometidos por projétil torna-se mais complexo quando esse está localizado em uma área de difícil acesso e ao lado de estruturas nobres. Técnicas radiográficas, obtidas por meio de diferentes planos, permitem uma localização precisa do objeto. Grande deformidade e incapacidade funcional podem ocorrer, especialmente, se o nervo facial é afetado durante o trauma balístico ou durante o ato cirúrgico. Apesar de náo haver lesôes nervosas, o comprometimento funcional das estruturas orofaciais foi decisivo para indicar o procedimento cirúrgico. A remoção cirúrgica do projétil da fossa infratemporal combinado com a fisioterapia, pós-operatória, mostraram ser um tratamento eficaz.

Descritores: Articulaçáo temporomandibular, Fossa infratemporal, Projetil, Reabilitação.

\section{INTRODUCTION}

It is difficult to calculate the actual incidence of facial gunshot injuries. In a retrospective study about body wounds caused by war projectiles, $6.9 \%$ of injuries affected the face ${ }^{1}$. The majority of such maxillofacial gunshot wounds were caused by suicide attempts, mostly committed by young men ${ }^{1}$.

In general, facial gunshot injuries have fatal results. However, depending on the penetration trajectory, location and destruction power, the projectile or its fragments may not cause direct damage to soft and hard tissues. However, it is recommended that maxillofacial gunshot wound victims should be transported to duly equipped surgery and trauma centers to revert facial, cranial and neurologic damage. Approximately $40 \%$ of cases require 
emergency interventions ${ }^{2}$.

Sometimes, the option is not to remove fragments, which probably will become encapsulated just requiring a scheduled clinical follow-up ${ }^{3}$. This is because in patients with retained projectiles, lead $(\mathrm{Pb})$ serum levels are of concern due to possible toxicity. The clinical relevance of this finding is not clear, but one should consider long-term poisoning, especially in children, elderly and systemically impaired patients. Furthermore, retained fragments may cause severe infections, such as meningitis if there is migration of micro-organisms to central nervous system ${ }^{4}$.

Because of possible systemic, neurological and vascular complications, it is important to accurately locate the fragment. If surgical intervention is necessary, the most adequate access for projectile removal should be chosen.

This study aimed at reporting a case of therapeutic intervention related to the surgical removal of a projectile located in the left infratemporal fossa, in addition to discussing management, its risks and complications.

\section{CASE REPORT}

Male patient, 18 years old, sought for treatment ten days after being shot in the face by a projectile caliber 22. During anamnesis, patient reported pain, limited mouth opening and difficulty to perform right laterality movement. Physical exam revealed injury in the left zygomatic area (Figure 1), the interincisal distance of which was $20.01 \mathrm{~mm}$. Patient presented no sensory, autonomic or motor impairment during evaluation.

Lateral and forward radiographies showed the projectile located medially to the left mandibular condyle (Figures 2, A and B) within the infratemporal fossa.

Based on signs, symptoms and images, a surgery aimed at removing the projectile, followed by physiotherapy was proposed and the patient accepted the treatment by signing the free and informed consent term.

Patient underwent general anesthesia with right-sided nasotra-

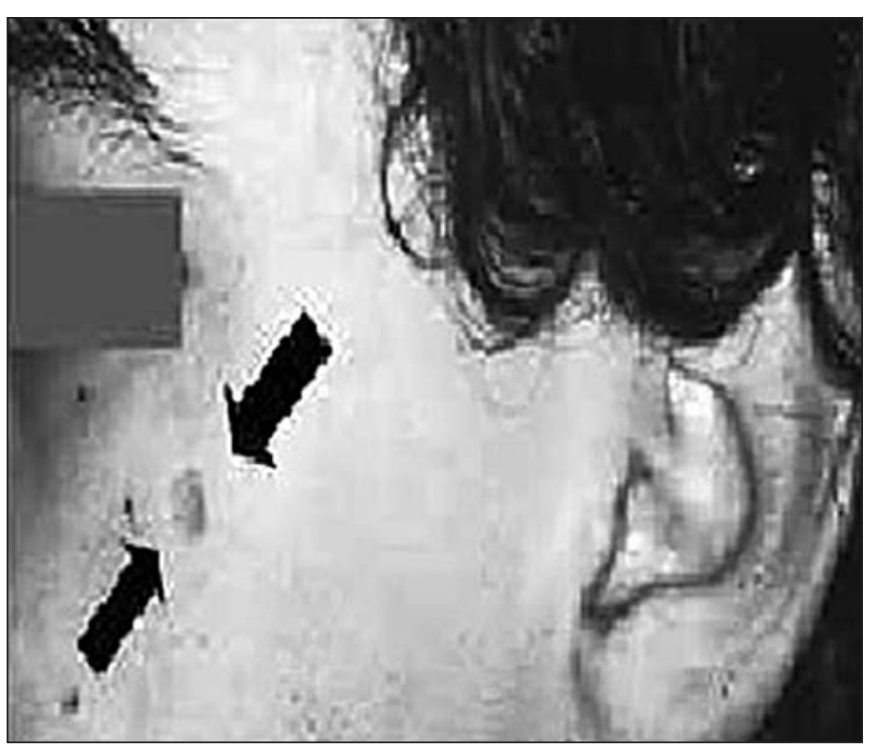

Figure 1. Blunt injury (arrows) in left zygomatic area

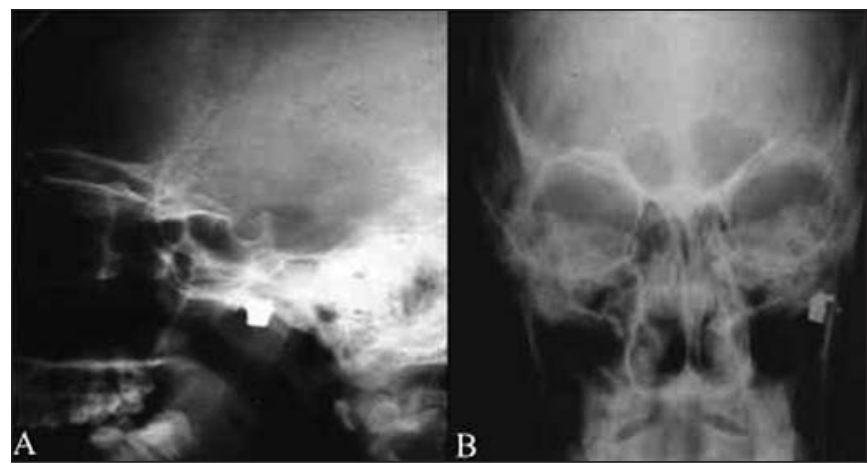

Figure 2. A-Lateral radiography, presence of a projectile located in the infratemporal fossa; B- Forward radiography, the projectile is located in anatomical space corresponding the infratemporal fossa.

cheal intubation. Furthermore, antisepsis with $2 \%$ chlorhexidine and apposition of the surgical area were performed, being the left ear and the left lateral corner of the eye visible and acoustic meatus was tamponed with gauze. The preauricular area was then stained with methylene blue followed by local infiltration with $2 \%$ lidocaine chlorhydrate with vasoconstrictor $(1: 100,000)$. A 15-minute interval was maintained for anesthetic solution to act and then skin and connective tissue were incised toward the superficial layer of the temporal fascia. Superficial temporal vessels and auriculo-temporal nerve were retracted anteriorly with the flap and use of 2 Senn-Miller retractors to avoid damaging them. Temporal fascia was obliquely incised in anteroposterior direction over the zygomatic arch. Then, deep dissection was started to visualize the most superficial surface of the temporomandibular and capsular ligaments, respectively, with joint eminence palpation. The next step involved detachment with periosteum elevator downward, reaching superior head of lateral pterygoid muscle. With the same instrument, we proceeded in the anterior and inferior direction to locate the inferior head of lateral pterygoid muscle. The region between both heads was carefully explored with Matzenbauer scissors aiming at minimizing the chances of damaging the maxillary artery and also at locating the projectile. Projectile was removed with the help of a Halsted anatomic clamp (Figure 3). Layers were closed from inside to outside with Vycril 4-0. The skin was closed with 6-0 Polypropilene (Prolene) and protected with a gauze overlay. The suture was removed at intervals from the 5 th to the 7 th postoperative day.

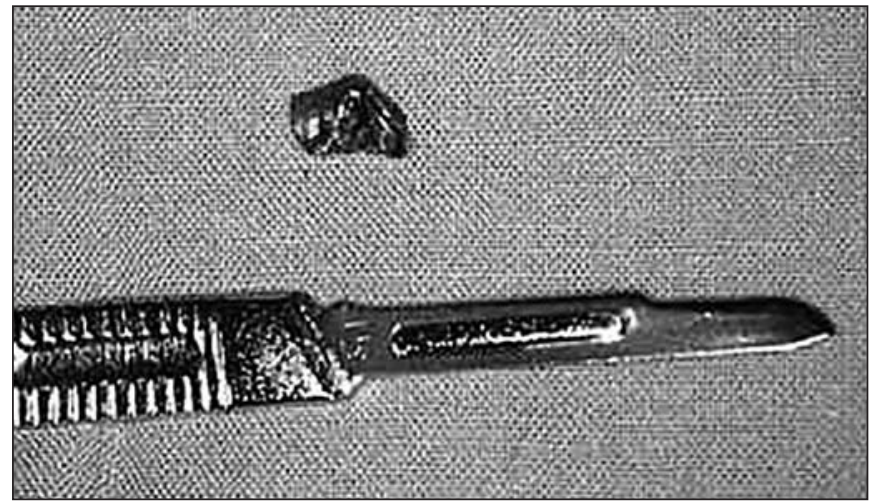

Figura 3. Projectile removed 
Postoperative course went without complications and patient started physiotherapy 7 days after leaving hospital. Physiotherapy sessions were performed twice a week for three months. These sessions involved $1.5 \mathrm{w} / \mathrm{cm}^{2}$ ultrasound on the left area for 5 minutes, associated to overlapping wooden spatulas, in addition to moist hot towels and passive stretching exercises for mouth opening, closing and lateral jaw movement. New postoperative radiographic exams, similar to previous exams, showed that the projectile was no longer there (Figure 4, A and B). Patient presented no sensitive, autonomic or motor impairment. Follow up revealed that patient had mouth opening of $40.02 \mathrm{~mm}$, without pain and lateral jaw limitation.

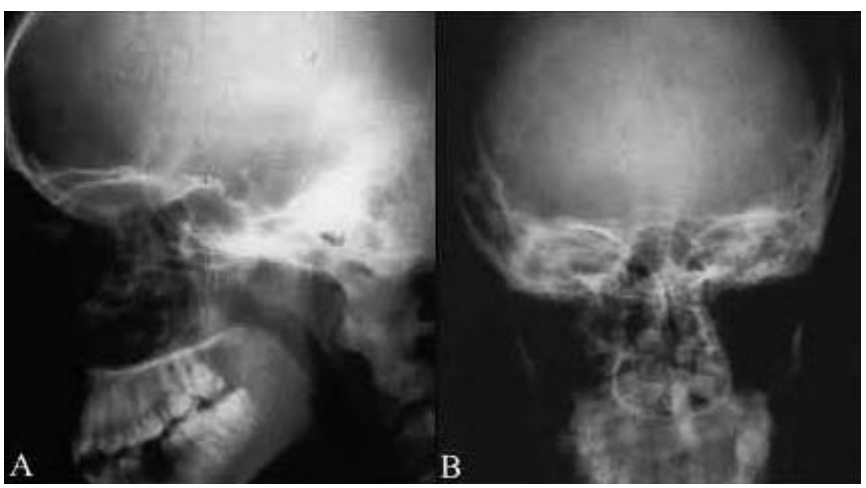

Figure 4. Lateral $(\mathrm{A})$ and forward $(\mathrm{B})$ radiographs post-surgical Note the absence of the projectile.

\section{DISCUSSION}

The literature reports that head and face are places commonly reached by gunshot injuries 5 . In general, there are major deformities and functional incapacity, especially when temporomandibular joint, facial nerve and deep skull and face structures are involved. A region possibly reached by this injury is the infratemporal fossa, which being close to the temporal fossa is delimited between surfaces of zygomatic, temporal, major wing of the sphenoid bone and ramus of mandible $e^{5}$ In this area, noble structures of major functional importance are present such as lateral and medial pterygoid muscles, the pterygoid venous plexus, the optic ganglion, the cord of tympani nerve, the mandibular nerve and one of its branches, and the lingual nerve, in addition to the maxillary artery, the pathway of which is superficial or deep below lateral pterygoid muscle 5 .

In case of injury of this fossa, there might be several complications, including jaw displacement, limited mouth opening, impairment of excursive jaw movements, development of anterior open byte and temporomandibular ankylosis ${ }^{6}$. Other more severe complications may also occur if immediate clinical and surgical measures are not taken, such as arterio-venous damage involving ptetygoid venous plexus and/or maxillary artery, involved masticatory and/or facial muscles, joint fibrotic ankylosis, infection, parotid gland changes, decreased or absence of taste sensitivity, lateral and anterior tongue border hypoesthesia, in addition to pain while speaking.

Immediate risks and complications of gunshot wound were not confirmed during evaluation of patient's clinical presentation, however, surgery for projectile removal was indicated due to pain and functional impairment of jaw movements. The physical presence of the foreign body associated to local edema involving both left lateral pterygoid muscle heads, was clinically manifested by pain at mouth opening and laterality movements to the right. If the projectile was stable in a soft or hard tissue structure not causing pain or masticatory impairment, a more conservative clinical approach associated to physiotherapy could be preferred ${ }^{7}$ being also recommended clinical and imaging follow up.

The preauricular approach was chosen for allowing adequate local exposure, with excellent view of the region, for being esthetically favorable and acceptable, in addition to minimizing risks of facial nerve injury ${ }^{5}$. Despite the choice of the most adequate surgical incision, the deep and unique location of the projectile between both heads made difficult its access. Insertions of this muscle in capsule, joint disk and neck of mandible structures could be impaired, resulting in other functional damages. Dissection for access could also be influenced by the anatomic variation of this muscle, expressed by different ways of insertion or its disposition in three heads ${ }^{5}$.

Regardless of surgical access - endaural, preauricular or post-auricular - the risk of damaging the facial nerve should always be considered, especially its temporal branches or, less frequently the zygomatic branch and the trigeminal auriculotemporal ner$\mathrm{ve}^{5,6}$. However, in this reported case, there has been no nervous damage, that is, motor, sensitive or autonomic damage observed during postoperative follow-up.

As exploratory surgical alternative, trans-surgical endoscopy could have been used, which has as advantages the access to different body areas with less need of dissection, decreasing tissue morbidity as compared to open surgery ${ }^{8}$. A paper is mentioned in the literature where authors have successfully removed a bullet from the infratemporal fossa by endoscopy with intraoral access ${ }^{8}$. However, such approach requires experience and training of the medical team for its indication, in addition to availability of specific and expensive equipment, which has made unfeasible its use in this case.

Available imaging exam at the moment was not the most accurate since the radiograph was unable to show the condition of adjacent soft tissues, in addition to offering bidimensional images. Exams with higher diagnostic precision could evaluate injury-related tissue damages before surgery. Literature mentions the use of nuclear magnetic resonance, ultrasound imaging, computerized tomography and computerized tomography with tapered beam as accurate methods to locate projectiles or foreign bodies as a consequence of face wounds ${ }^{9}$. However, these devices are expensive and usually are not available for public health assistance. So, as diagnostic alternative, we have used radiographic exposures in different planes (forward and lateral) to estimate the tridimensional location of the projectile, which has also provided the evaluation of surrounding bone structures.

Physiotherapy prescribed after surgery, together with ultrasound therapy and superficial moist heat aimed at restoring joint functioning, relieving pain, decreasing edema, promoting neuromuscular reeducation of masticatory muscles, decreasing reflex muscle contractures and preventing intra-articular adhesions ${ }^{10}$. 
Therapeutic exercises to improve mouth amplitude with wooden spatulas have also promoted stabilization of results and restoration of proprioception ${ }^{10}$.

\section{CONCLUSION}

Projectile removal with preauricular approach associated to combined physiotherapeutic treatment has provided joint function reestablishment, pain elimination, an appropriate mouth opening without facial sensitive, autonomic and motor sequelae.

\section{REFERENCES}

1. Norris O, Mehra P, Salama A. Maxillofacial Gunshot Injuries at an Urban Level I Trauma Center-10-Year Analysis. J Oral Maxillofac Surg. 2015;73(8):1532-9.

2. Maurin O, de Régloix S, Dubourdieu S, Lefort H, Boizat S, Houze B, et al. Maxillo- facial gunshot wounds. Prehosp Disaster Med. 2015;30(3):316-9.

3. Farrell SE, Vandevander P, Schoffstall JM, Lee DC. Blood lead levels in emergency department patients with retained lead bullets and shrapnel. Acad Emerg Med. 1999;6(3):208-12

4. Brinson GM, Senior BA, Yarbrough WG. Endoscopic management of retained airgun projectiles in the paranasal sinuses. Otolaryngol Head Neck Surg. 2004;130(1):25-30.

5. Isolan GR, Rowe R, Al-Mefty O. Microanatomy and surgical approaches to the in fratemporal fossa: an anaglyphic three-dimensional stereoscopic printing study. Skull Base. 2007;17(5):285-302.

6. Pires MS, Giongo CC, Antonello G de M, Couto RT, Filho R de O, Junior OL. An interesting case of gunshot injury to the temporromandibular joint. Craniomaxillofac Trauma Reconstr. 2015;8(1):79-82.

7. Oh DW, Kim KS, Lee GW. The effect of physiotherapy on post-temporomandibular joint surgery patients. J Oral Rehabil. 2002;29(5):441-6.

8. Neff LL, Liess BD, Chang CW. Transoral endoscopic removal of a bullet from the infratemporal fossa. Otolaryngol Head Neck Surg. 2008;138(1):113-4.

9. Daghfous A, Bouzaïdi K, Abdelkefi M, Rebai S, Zoghlemi A, Mbarek M, et al. Contribution of imaging in the initial management of ballistic trauma. Diagn Interv Imaging. 2015;96(1):45-55.

10. Stockmann P, Vairaktaris E, Fenner M, Tudor C, Neukam FW, Nkenke E. Conventional radiographs: are they still the standard in localization of projectiles? Oral Surg Oral Med Oral Pathol Oral Radiol Endod. 2007;104(4):e71-5. 